\title{
Analysis of the Construction and Utilization of Digital Resources in Financial and Economic College Libraries-Taking Shandong Technology and Business University as an Example
}

\author{
Li Xihong \\ Library of Shandong Technology and Business University \\ Yantai, Shandong, 264005
}

\begin{abstract}
Digital resources have unmatched advantages over paper resources and gradually become the focus of university library resources development. However, how to properly plan resource structure and improve resource utilization is a problem that every university library should consider. Through investigating the digital resource construction and utilization of the library of Shandong Technology and Business University, it is found that there are problems such as insufficient funds, unreasonable structure, ageing librarians and lack of high-end services. The author's recommendations are as follows: take joint and sharing construction, optimize the structure, cultivate new types of librarians and take other reasonable measures, and constantly improve the library's digital resource system to provide readers with quality services.
\end{abstract}

Keywords-Financial and economic universities; Digital resources; Construction; Utilization; Recommend

\section{INTRODUCTION}

Digital resources are greatly appreciated by readers due to their large capacity, easy storage, easy retrieval and fast update [1]. Therefore, digital resources are becoming an important part in the construction of university library resources. As a financial and economical university, the library of Shandong Technology and Business University has always considered the construction of digital resources as an important task for the construction of library resources. The university always combines the discipline construction and the research development planning closely to purchase digital resources. While safeguarding key disciplines, the university also constantly expands resources for new disciplines. After nearly a decade of construction, the digital resources of the library have formed a collection structure that focuses on economics and management, and takes science, engineering, literature, law and philosophy into consideration. At the same time, it highlights the feature of "coal economy and peninsula economy".

\section{A. Digital Resource Development}

There are three forms of digital resources construction in the library of the Shandong Technology and Business University. One is the introduction of digital resources, the second is self-built resources, and the third is the integration of high quality open access (OA) and free resources.

By the end of 2017, the library has ensured the purchase of 32 kinds of high-quality Chinese and foreign resources through three channels, namely, university library digital resource procurement, university group procurement in Shandong province and single-source procurement. With limited funds, OA resources are favored by various libraries and research institutions for their advantages of free of charge, openness, and sharing". It has also become a powerful complement to library digital resources. Combined with college discipline setting and discipline development planning, the library integrates more than 40 types of $\mathrm{OA}$ and free resources, including dissertations, electronic journals, institutional academic libraries, electronic papers, e-books and multimedia resources and other resources. These high quality OA or free resources play an important role in supplementing library collections. In the spirit of exploiting its own advantages, it has actively explored its own resources. After nearly a decade of construction, it has built four digital resources, namely the Peninsula Economic Characteristics Database, the Coal Economic Characteristics Database, Shandong Business Library and Graduate Dissertation Platform of Shandong Technology and Business University. See Table 1 for details. 
TABLE I. MAIN LibRARY DigITAL ReSOURCES

\begin{tabular}{|c|c|c|c|c|c|}
\hline & Serial number & Name of database & & $\begin{array}{l}\text { Serial } \\
\text { number }\end{array}$ & Name of database \\
\hline \multirow{9}{*}{$\begin{array}{c}\text { Main } \\
\text { Chinese } \\
\text { database }\end{array}$} & 1 & $\begin{array}{c}\text { China National } \\
\text { Knowledge } \\
\text { Infrastructure(CNKI) }\end{array}$ & \multirow{5}{*}{$\begin{array}{c}\text { Main } \\
\text { Foreign } \\
\text { language } \\
\text { database }\end{array}$} & 10 & EBSCO Foreign language database \\
\hline & 2 & $\begin{array}{l}\text { Duxiu Knowledge } \\
\text { Search Database }\end{array}$ & & 11 & $\begin{array}{c}\text { Emerald Economic Management Journal } \\
\text { Database }\end{array}$ \\
\hline & 3 & $\begin{array}{c}\text { Superstar mobile } \\
\text { library }\end{array}$ & & 12 & $\begin{array}{l}\text { PQDT Master's degree thesis full-text } \\
\text { database }\end{array}$ \\
\hline & 4 & $\begin{array}{c}\text { New Oriental } \\
\text { multimedia learning } \\
\text { library }\end{array}$ & & 13 & IEEE Computer Society Digital Library \\
\hline & 5 & $\begin{array}{l}\text { JCR Journal Partition } \\
\text { Table in } 2016\end{array}$ & & 14 & Encyclopedia Britannica \\
\hline & 6 & $\begin{array}{c}\text { State Council } \\
\text { Development and } \\
\text { Research Center } \\
\text { Information Network }\end{array}$ & \multirow{4}{*}{$\begin{array}{c}\text { Self- } \\
\text { built } \\
\text { database }\end{array}$} & 15 & Peninsula Economic characteristics Library \\
\hline & 7 & $\begin{array}{l}\text { VIP Information } \\
\text { Chinese sci-tech } \\
\text { journal full-text } \\
\text { database }\end{array}$ & & 16 & Coal economic characteristics database \\
\hline & 8 & $\begin{array}{l}\text { (CSMAR)China stock } \\
\text { market trading } \\
\text { database }\end{array}$ & & 17 & Shandong business library \\
\hline & 9 & $\begin{array}{c}\text { Airitilibrary Taiwan } \\
\text { Academic Literature } \\
\text { Database(edition of } \\
\text { People's Publishing } \\
\text { House)(Added) }\end{array}$ & & 18 & Graduate degree thesis platform \\
\hline
\end{tabular}

The three forms of resources form a digital resource pattern that focuses on the introduction of resources, supplemented by OA, free resources and self-built resources.

\section{B. Utilization of Digital Resources}

In order to understand the use of various resources by readers, the library conducts special statistics on visits and downloads of digital resources at the end of 2017. 
1) Utilization Of Major Imported Chinese Resources

TABLE II. UtilizATION OF MAJOR Chinese Digital ResourCes IN 2017

\begin{tabular}{|c|c|c|c|}
\hline Serial number & Name of database & $\begin{array}{l}\text { Amount of access } \\
\text { (second) }\end{array}$ & proportion \\
\hline 1 & $\begin{array}{c}\text { China National Knowledge Infrastructure } \\
\text { (Academic Journals , Masters' Theses\& Doctoral } \\
\text { Dissertations Full-text Database) }\end{array}$ & 14893182 & $84 \%$ \\
\hline 2 & duxiu book search engine & 569024 & \multirow[t]{2}{*}{$7.8 \%$} \\
\hline 3 & Chaoxing Digital Library; & 806235 & \\
\hline 4 & $\begin{array}{l}\text { VIP Information Chinese sci-tech journal full-text } \\
\text { database }\end{array}$ & 791180 & $4.5 \%$ \\
\hline 5 & $\begin{array}{c}\text { Development Research Center of the State Council } \\
\text { Information Network }\end{array}$ & 75765 & $0.4 \%$ \\
\hline 6 & (CSMAR)China stock market trading database & 4379 & - \\
\hline 7 & Edu\&Sun Education employment Database & 56168 & $0.3 \%$ \\
\hline 8 & Edu\&Sun online Reporting Hall & 76345 & $0.4 \%$ \\
\hline 9 & Vipexam Training \& Learning Resource Database & 85917 & $0.5 \%$ \\
\hline 10 & China Inforbank Finance and Economics Database & 21814 & \multirow{2}{*}{$0.3 \%$} \\
\hline 11 & Sohoo Database & 32239 & \\
\hline 12 & $\begin{array}{c}\text { Airitilibrary Taiwan Academic Literature } \\
\text { Database(edition of People's Publishing House) } \\
\text { (Added) }\end{array}$ & 4091 & - \\
\hline 13 & New Oriental Multimedia Learning Library & 1006615 & - \\
\hline 14 & Coal Digital Library & 1032 & -— \\
\hline 15 & $\begin{array}{c}\text { (AMLC) CNKI Academic Misconduct Detection } \\
\text { System }\end{array}$ & 533 & 一 \\
\hline 16 & JCR Journal Partition Table in 2016 & 1320 & \\
\hline 17 & NoteExpress Document Management Software & 19437 & $0.1 \%$ \\
\hline 18 & China Librariy and Information & 23136 & \multirow{2}{*}{$0.3 \%$} \\
\hline 19 & FirstLight Knowledge Navigation & 32239 & \\
\hline & Total & 17638738 & \\
\hline
\end{tabular}

In the statistical data, the visitor volume is provided by the data resource providers, consolidating periodicals, doctoral theses, and master's theses from China National Knowledge Infrastructure (CNKI). From Table 2, it is easy to be seen that among all the Chinese databases that are introduced in 2017, CNKI has the largest number of visits and downloads, reaching 14.89 million, accounting for $84 \%$ of all introduced Chinese resources, which conforms to the characteristics of our college that focus on undergraduate teaching. The number of visits to the Duxiu Academic Search and Superstar Library is 569,000 , accounting for $7.8 \%$ of the total, second only to CNKI. The VIP database ranks third, with 771,000 downloads, accounting for $4.5 \%$. State Council Development Research Center Information Network and Information Bank University Financial Database are used as fact-type databases. Although the utilization rate is not high, it is an important resource guarantee for the college's economic and management specialties. In addition, there is a high utilization rate for exam and study databases, such as New Oriental Multimedia Learning Database, VIPExam Database and so on.

Compared with 2016, the number of visits to Chinese resources generally have showed an upward trend, where the number of visits to the Chinese stock market database has increased fastest, followed by Superstar Mobile Library. CNKI visits have consistently ranked first in the introduction of data resources, while New Oriental multimedia learning library visits has declined. The new introduction of airitilibrary Taiwan academic literature database (edition of People's Publishing House) has also received readers' attention and welcome.

\section{2) Utilization Of Imported Foreign Resources}

Compared with Chinese digital resources, readers have less demand for foreign digital resources. Table 3 shows that in the imported foreign language resources, the total number of visits reaches 822,633 in 2017, where EBSCO has the highest number of visits, 37,344 visits, accounting for $45 \%$ of 
all foreign language resources, followed by the Emerald database with 19,775 visits, accounting for $24 \%$, which conforms to the characteristics of Shandong Technology and Business University as a financial university, while the PQDT only accounts for $1.5 \%$ and SAGE $0.6 \%$. It can be seen that the use of foreign language resources is very uneven.

TABLE III. UTILIZATION OF MAJOR ForeIgN LANGUAGE RESOURCES IN 2017

\begin{tabular}{|c|c|c|c|}
\hline Serial number & Name of database & $\begin{array}{c}\text { Amount of access } \\
\text { (second) }\end{array}$ & proportion \\
\hline 1 & EBSCO Database & 37344 & $45 \%$ \\
\hline 2 & Emerald Database & 19775 & $24 \%$ \\
\hline 3 & PQDT Masters' \& Doctoral Dissertations Full-text \\
Database & 1227 & $1.5 \%$ \\
\hline 4 & Encyclopedia Britannica Online Database & 15835 & $19 \%$ \\
\hline 5 & SAGE Backfiles Database & 477 & $6.4 \%$ \\
\hline 6 & MathSciNet Database & 5251 & $4 \%$ \\
\hline 7 & AMS Database & 3201 & 42633 \\
\hline
\end{tabular}

\section{EXISTING PROBLEMS}

\section{A. Insufficient Funds}

Shandong Technology and Business University, as a local institution, has insufficient financial appropriation, so the fund for the library is not enough, only about 4 million yuan available each year. Although the annual purchase cost for digital resources has increased year by year, for example, accounting for $42.5 \%$ of all resource funds by 2017, it is far behind the average of 2.881 million yuan [2] for the procurement of electronic resources for national university libraries in 2016.

\section{B. The Under Optimized Structure}

Shandong Technology and Business University has long been positioned as a teaching institution, so the main focus of the library is on teaching-based learning resources. However, in recent years, with the introduction of highly-educated teachers (such as doctoral students) in many universities, great changes have taken place in the structure of teachers' academic qualifications and the level of their needs; the teachers' essay creation and scientific research projects have been greatly enhanced. What's more, at the same time, Shandong Technology and Business University is also in the transition period from college to university. The demand for scientific research triggered by those two points has become apparent. At present, in the foreign language resources introduced by the library, table 2 shows that EBSCO's utilization rate is not low. But in reality, through surveys, it has been learned that college graduate readers have a strong demand for Elsevier. Meanwhile, the college's major discipline setting is based on economics and management, which has great demand for statistical data resources, but there are no digital resources for professional tools in the digital resources of libraries. Therefore, in view of the current digital resource structure of libraries, it is difficult to meet the needs of school readers in scientific research and it is urgently necessary to readjust it.

\section{Aging Librarians And Insufficient Service}

Digital resources play an important role in the construction of university library resources and development of scientific research in colleges and universities. The availability and utilization of resources have a great relationship with the quality of librarians and the level of knowledge. Through the survey, it is found that most of the student readers only use CNKI and know little about other digital resources. Librarians have an unshirkable responsibility for this. At present, the age structure of librarians of Shandong Technology and Business University is seriously aging. There are 38 librarians, of whom 18 are aged 50 and above, accounting for $47 \%, 10$ are $40-50$ years old, accounting for $26 \%$, and 8 are 40 years old and below, accounting only for $27 \%$. They have the low level of knowledge service is low and rigidly adhere to traditional service methods. In addition, they can't provide readers with timely services and high-quality ones of a certain height, breadth, and depth, which makes digital resources services lack for a long time.

\section{RECOMMENDATIONS}

\section{A. Co-construction and co-sharing of resources}

"In the era of network information, any single library cannot have all the information resources in the world, and it is impossible and unnecessary to collect all the information resources." [3] Therefore, resource cooperation or the establishment of a resource sharing mechanism is inevitable. Firstly, as a financial college, Shandong Technology and Business University can establish alliances with financial universities of the same type inside and outside Shandong Province to build and share professional resources. Secondly, as a local institution, it can actively strengthen cooperation 
with local colleges and universities such as Yan Tai University, LuDong University and BinZhou Medical College Yantai Campus, which is also a wise choice for expanding the scale of digital resources. Thirdly, it can strengthen cooperation with local public libraries, jointly building and sharing some local digital resources. Through cooperation and sharing within and between regions, a complete digital resource service system will be constructed.

\section{B. Optimization of the Structure}

Shandong Technology and Business is transforming from teaching-oriented universities to university attaching equal importance to teaching and scientific research. Under such guidance, the digital resource construction direction of its library will also change. Firstly, the library should focus on the development of the teaching resource needs of the schools' advantageous subjects (such as management and economy) [4] Secondly, the library should strengthen the construction of digital resources for higher-level scientific research needs. After a long period of development, the digital resource structure has been gradually improved and adjusted.

\section{Training of new subject librarians and opening discipline navigation service}

"High-quality professional talents are a powerful guarantee for the library to carry out modernization and provide readers with high-level and in-depth services."[5] Under the new circumstances, the cultivation of new-type subject librarians has become the most urgent task for Shandong Technology and Business University. It can be carried out in two ways. First, regular professional training for existing young librarians will enable them to rapidly grow into competent librarians. Second, introduce new high-level talents with multidisciplinary expertise in library, intelligence, computers, foreign languages and bibliometrics. Simultaneously, the university should build a rational talent structure for the library and cultivate a new type of subject librarian, thereby "entering the frontline and embed process, coordinating the power of the entire museum and all aspects and providing users with the services of subjects, knowledge and personalization under the background of academic exchanges and on the basis of the needs of the discipline users."[6]

\section{Full Play of the Document Delivery Function}

Because of tight funds, local colleges and universities are impossible to purchase all databases. In order to meet the different needs of readers, they can use the CALIS document delivery function of China's higher education literature guarantee system to cover social sciences, natural sciences and other disciplines. Besides, there are a variety of literature types, a large number of documents and abundant resources. All member and center libraries of CALIS system can provide services for other member libraries, which is an important guarantee for local universities to provide digital resource services.

\section{CONCLUSION}

Digital resources are and will be the main direction of the university library resource construction. In order to provide readers with personalized, diversified and high-end service, financial and economic institutions should combine the special features, discipline construction and scientific research needs to build a resource system suitable for the readers of this school.

\section{REFERENCES}

[1] Yang Ying. Investigation and Analysis of Electronic Resources Construction in University Libraries in Hainan Province [J]. Journal of Modern Intelligence, 2007(3): 100-104.

[2] Qin Bo, Zhou Lihong. Talking about the Conception of Digital Resources Construction in Local College Libraries [J]. Journal of Modern Intelligence, 2008(3): 99-101.

[3] Du Hao. Study on Collection Construction of ESI Source Journal Based on "Two-class" Discipline Construction [J]. Jiangsu Science and Technology Information, 2017(31): 23-25.

[4] Hao Fengsu, Yang Yongmei, Jin Hong. The Characteristics and Model Comparison of Subject Service in University Library[J]. Library Journal, 2009(4): 51-53.

[5] Sun Xiuli. Investigation and Analysis of Construction and Utilization of Digital Resources in University Libraries[J]. Journal of Academic Libraries, 2008(6): 45-50.

[6] Wang Guiling. Network Resources Subject Navigation and DC Metadata[J]. Journal of Modern Intelligence, 2005(8): 209-210. 